\title{
Serum Potassium Levels and Adverse Outcomes in Patients with Acute Myocardial Infarction
}

\section{Rizwan Abbas, ${ }^{1}$ Tazeen Nazar, ${ }^{2}$ Bilal Aziz, ${ }^{3}$ Furqan Saeed, ${ }^{4}$ Kashif Nawaz, ${ }^{5}$ Muhammad Nabeel $^{6}$}

\begin{abstract}
Objective: To determine the effect of serum potassium levels on short term mortality outcomes in patients with acute myocardial infarction.

Methods: This Descriptive Case Series was conducted in the CCU of Mayo Hospital Lahore from 15th November, 2017 to 15 th May, 2018. A total of 156 patients of either sex between the age group of 30-60 years and diagnosed as cases of myocardial infarction with symptoms of less than 24 hours duration and serum potassium level of $<3.5 \mathrm{mEq} / \mathrm{L}$ were included in the study. Patients were then followed up for 7 days and adverse outcome was recorded. Data was analyzed using computer software SPSS Version 22.0.

Results: Out of the 156 patients, $119(76.3 \%)$ were males and $37(23.7 \%)$ were females. Mean age of the patients was $47.88 \pm 6.24$ years, mean weight $85.31 \pm 13.14 \mathrm{Kg}$, mean duration of presenting complaints was 10.269 \pm 4.51 hours and mean Serum Potassium levels were $3.05 \pm 0.25 \mathrm{mEq} / \mathrm{L}$. Adverse outcome in the form of mortality due to arrhythmias was seen in $15(9.6 \%)$ patients.

Conclusion: Low serum potassium level $(<3.5 \mathrm{mEq} / \mathrm{L} / \mathrm{L})$ was significantly associated with increased adverse outcome in acute myocardial infarction patients.

Keywords: Acute myocardial infarction, Low serum potassium levels, Adverse outcome

How to cite: Abbas R., Nazar T, Aziz B., Saeed F., Nawaz K., Nabeel M. serum potassium levels and adverse outcomes in patients with acute myocardial infarction. Esculapio 2021;17(01):5-8

DOI: https://doi.org/10.51273/esc21.251711
\end{abstract}

\section{Introduction}

$\mathrm{P}$ otassium homeostasis is vital in preventing adverse effects in patients having cardiovascular disease. Numerous studies have shown an association of low levels of serum potassium, frequently less than $3.5 \mathrm{mEq} / \mathrm{L}$, with the risk of having ventricular arrhythmias in acute myocardial infarction(AMI) patients. ${ }^{1}$ Two neurohormonal mechanisms have been proved to play a key role in AMI: the renin - angiotensinaldosterone system and the adrenergic autonomic nervous system. ${ }^{1}$ Damage to the myocardium, systolic or diastolic dysfunction, peripheral hypoperfusion and hypertension of pulmonary veins all contribute to

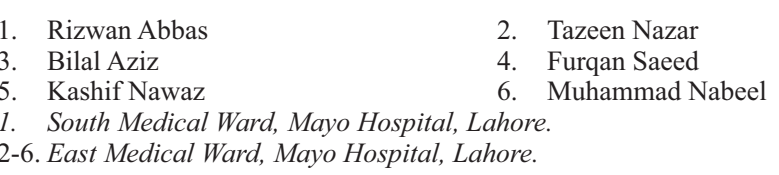

\section{Correspondence:}

Dr. Bilal Aziz, East Medical Ward, Mayo Hospital, Lahore.

Email: bilal156@yahoo.com

Submission Date:

Acceptance Date:

15-12-2020

08-02-2021 activation of neurohormonal response that maintains homeostasis and also contributes to further injury. Serum potassium levels are maintained in humans in the 3.5 to $5.0 \mathrm{mEq} / \mathrm{L}$ range at organ, cellular and molecular levels. Neurohormonal response changes that occur in AMI are depicted in the serum potassium levels and response of the body in maintaining a normal range. ${ }^{2}$

Hypoperfusion of the kidneys and vasoconstriction at the pre-glomerular level contributes to a decreased glomerular filtration thereby leading to potassium retention and hyperkalemia. Aldosterone release favours hypokalemia through reabsorption of sodium and exchange of potassium. Krogager et al. followed cases registered with the Danish health services and investigated the relationship between serum potassium levels taken at seven different defined intervals and deaths attributed to any cause within ninety days in patients after an AMI. ${ }^{3}$ The survival analysis of the patients were based on the first measurement of serum potassium and in order to reduce bias, day 0 i.e., the day of presentation and day 1 were eliminated. 
As expected, levels of serum potassium not falling within the reference range were associated with higher risk of death and depicted through a specific Ushaped curve. This finding was not unfamiliar in patients with AMI. ${ }^{4-6}$ This report was subjected to multi-variate analysis and the findings reinforced the association of potassium levels falling in the range of 3.5-3.8 mEq/L (HR: 1.82; 95\% CI: 1.21-2.74) and 4.5-5.0 mEq/L (HR: 1.54; 95\% CI: 1.08-1.21) and an elevated death risk when compared with potassium levels in the 3.9-4.5 mEq/L range.

A study by Goyal A, et al. has shown that frequency of mortality was $11.4 \%$ in patients with low serum potassium levels with acute myocardial infarction. ${ }^{7}$

In another study by Uluganyan $\mathrm{M}$, et al., the frequency of mortality was $2.4 \%$ in patients with low serum potassium levels with acute myocardial infarction. ${ }^{8}$

The recent guidelines recommend to maintain a serum potassium level of $>4-4.5 \mathrm{mEq} / \mathrm{L}$ in AMI patients. ${ }^{\mathrm{b}}$ On the contrary, some clinical trials carried out recently have shown an increased death rate with serum potassium level of $>4-4.5 \mathrm{mEq} / \mathrm{L}{ }^{4,7}$ The aim of this study is to determine the effect of serum potassium levels on short term mortality of patients with acute myocardial infarction in our general population. This study will pave the way for further research in this field and will help to understand impact of low potassium levels on mortality rate in our general population.

\section{Methods}

This Descriptive Case Series was conducted in the Coronary Care Unit (CCU) of Mayo Hospital Lahore from 15th November 2017 to $15^{\text {th }}$ May 2018. A sample size of 156 cases was taken using $95 \%$ confidence level, $5 \%$ margin of error and taking expected frequency of adverse outcome in the form of mortality as 11.4\%.7 Non-Probability Consecutive Sampling Technique was applied in selection of the cases. Patients of either gender between the age group of 3060 years with the diagnosis of Myocardial Infarction as per operational definition and presentation to the hospital within 24 hours of onset of symptoms and having serum potassium level of $<3.5 \mathrm{mEq} / \mathrm{L}$ by laboratory test at the time of presentation were included in the study. Patients with the history of heart failure, renal failure defined by serum creatinine of $>2.2 \mathrm{mg} / \mathrm{dl}$ on laboratory test, presentation to the hospital more than 24 hours after the onset of symptoms and history of coronary artery bypass grafting were excluded from the study.

After approval from the Board of Studies (BOS) and Institutional Review Board (IRB) of King Edward Medical University, Mayo Hospital, Lahore, all patients conforming to the inclusion criteria were enrolled in the study. Written informed consent ensuring confidentiality and safety was taken from all the selected patients. Baseline demographic information of patients (age, gender, weight and duration of complaints) was taken. Baseline echocardiogram (ECG), serum troponin $\mathrm{T}$ and potassium levels were done. Patients were then followed up for the next 7 days and adverse outcome in the form of mortality was noted and recorded on a pre-designed proforma.

Data was analyzed using computer software SPSS version 22.0. Quantitative variables like age, serum potassium levels, duration of complaints and weight were presented as Mean \pm SD. Qualitative variables like age, gender and adverse outcome were presented in the form of frequency and percentages. Effect modifiers like age, gender, serum potassium levels, duration of complaints and weight were controlled by stratification. Post stratification chi-square test was applied and $p$-value of $\leq 0.05$ was considered statistically significant.

\section{Results}

The mean age of the patients was calculated to be $47.88 \pm 6.24$ years, mean weight was $85.31 \pm 13.14$ $\mathrm{Kg}$, mean duration of complaints was $10.26 \pm 4.51$ hours and mean Serum Potassium levels were $3.05 \pm$ $0.25 \mathrm{mEq} / \mathrm{L}$. Majority of the patients were in the age group of 46-60 years i.e., 102 (65.4\%) compared to 54 $(34.6 \%)$ patients in the $30-45$ years age group. There was a male gender predominance i.e., 119 (76.3\%) compared to 37 (23.7\%) females. Adverse outcomes in the form of mortality due to arrhythmias were seen in $15(9.6 \%)$ patients only. Stratification of adverse outcome with respect to age, gender, weight, duration of complaint and serum potassium levels are shown in Table-1-3 respectively.

\section{Discussion}

The results of this study showed that admission serum potassium level of $<3.0 \mathrm{mEq} / \mathrm{L}$ was associated with increased adverse outcome in patients with acute myocardial infarction. Hypokalemia i.e., serum potassium levels $<3.5 \mathrm{mEq} / \mathrm{L}$ in patients with acute myocardial infarction is primarily accredited to catechola- 
mine surge.$^{10}$ Catecholamines stimulate Na-K-ATPase pump and shift $\mathrm{K}+$ intracellularly, thereby leading to redistributional hypokalemia. This results in hypopolarization of the viable, non-ischemic myocardial

Table 1: Stratification of Adverse Outcome with Respect to Age, Gender and Weight

\begin{tabular}{|c|c|c|c|c|}
\hline \multirow{2}{*}{\multicolumn{2}{|c|}{ Parameters }} & \multicolumn{2}{|c|}{ Adverse outcome } & \multirow{2}{*}{$\begin{array}{c}P \\
\text { value }\end{array}$} \\
\hline & & Yes & No & \\
\hline \multirow[t]{3}{*}{ Age } & $30-45$ years & $6(11.1 \%)$ & $48(88.9 \%)$ & \multirow{3}{*}{0.645} \\
\hline & $46-60$ years & $9(8.8 \%)$ & $93(91.2 \%)$ & \\
\hline & Total & $15(9.6 \%)$ & $141(90.4 \%)$ & \\
\hline Gender & Male & $11(9.2 \%)$ & $108(90.8 \%)$ & \multirow{3}{*}{0.778} \\
\hline & Female & $4(10.8 \%)$ & $33(89.2 \%)$ & \\
\hline \multicolumn{2}{|c|}{ Total } & $15(9.6 \%)$ & $141(90.4 \%)$ & \\
\hline \multirow[t]{3}{*}{ Weight } & $\leq 70 \mathrm{~kg}$ & $2(5.4 \%)$ & $35(94.6 \%)$ & \multirow{3}{*}{0.320} \\
\hline & $>70 \mathrm{~kg}$ & $13(10.9 \%)$ & $106(89.1 \%)$ & \\
\hline & otal & $15(9.6 \%)$ & $141(90.4 \%)$ & \\
\hline
\end{tabular}

Table 2: Stratification of adverse outcome with respect to duration of complaints

\begin{tabular}{cccc}
\hline \multirow{2}{*}{$\begin{array}{c}\text { Duration of } \\
\text { complaint (hours) }\end{array}$} & \multicolumn{2}{c}{ Adverse outcome } & \multirow{2}{*}{$\begin{array}{c}\text { A } \\
\text { value }\end{array}$} \\
\cline { 2 - 3 } & Yes & No & \\
\hline $1-12$ & $3(2.8 \%)$ & $104(97.2 \%)$ & $\mathbf{0 . 0 0 0}$ \\
$13-23$ & $12(24.5 \%)$ & $37(75.5 \%)$ & \\
Total & $15(9.6 \%)$ & $141(90.4 \%)$ & \\
\hline
\end{tabular}

Table 3: Stratification of adverse outcome with respect to serum potassium levels

\begin{tabular}{|c|c|c|c|}
\hline \multirow{2}{*}{$\begin{array}{l}\text { Serum potassium } \\
\text { levels }(\mathrm{mEq} / \mathrm{L})\end{array}$} & \multicolumn{2}{|c|}{ Adverse outcome } & \multirow{2}{*}{$\begin{array}{c}\mathbf{P} \\
\text { value }\end{array}$} \\
\hline & Yes & No & \\
\hline$<3.0$ & $10(21.7 \%)$ & $36(78.3 \%)$ & \multirow{3}{*}{0.001} \\
\hline $3.0-3.4$ & $5(4.5 \%)$ & $105(95.5 \%)$ & \\
\hline Total & $15(9.6 \%)$ & $141(90.4 \%)$ & \\
\hline
\end{tabular}

tissue and electrical non-homogeneity responsible for causing ventricular arrhythmias. Previous studies have shown a high incidence of ventricular arrhythmia within a few days following MI and associated it with hypokalemia.11 Although most of these studies were carried out during the time when modern treatment options like beta-blocker and early reperfusion therapy were not available. So guidelines were formulated to maintain a serum $\mathrm{K}+$ level of $>4-4.5 \mathrm{mEq} / \mathrm{L}$ in patients following acute MI. ${ }^{12,13}$ Beta-blockers cause an increase serum potassium level and suppress ventricular arrhythmias by depressing $\mathrm{K}+$ levels induced through catecholamine surge. Beta-2 receptors inhibit the $\mathrm{Na}+-\mathrm{K}+$-ATPase pump and contribute to the catecholamine surge. ${ }^{14}$ Studies have shown that if beta blockers are administered early in the post
STEMI period, then a decreased incidence of ventricular arrhythmias, sudden cardiac death and mortality were observed. ${ }^{15,16}$

A study conducted by Goyal A et al showed 11.4\% mortality in patients with low serum potassium levels following acute myocardial infarction. ${ }^{7}$ However, a study performed by Goyal et al.7 on a larger population, surprisingly related a mean serum $\mathrm{K}+$ level above $4.5 \mathrm{mEq} / \mathrm{L}$ to be associated with increased mortality. This led to a suggestion that in patients with AMI, serum $\mathrm{K}+$ level should be optimized within the 3.5 and $4.5 \mathrm{mEq} / \mathrm{L}$ range. ${ }^{7}$ This proposal posed a challenge to the guidelines recommended for $\mathrm{K}+$ level. Recently a study carried out by Choi and colleagues 4 supported the findings of Goyal et $\mathrm{al}^{7}$. They proved mean serum $\mathrm{K}+$ level of $>4.5 \mathrm{mEq} / \mathrm{L}$ to be associated with increased hospital and delayed mortality. ${ }^{4}$ Although beta blockers and angiotensinconverting enzyme inhibitors were not used often for the treatment of high potassium levels $>4.5 \mathrm{mEq} / \mathrm{L}$ in that study, it was still associated with higher longterm deaths. ${ }^{4}$ Even though our study took serum $\mathrm{K}+$ level at the time of admission rather than taking mean $\mathrm{K}+$, it showed congruity with Choi and Goyle studies. This finding was facilitated by Choi and colleagues. ${ }^{4}$ A possible explanation could be low $\mathrm{K}+$ levels responsible for compromising myocardial contractility and relaxation mainly due to high levels of vasopressors. ${ }^{17}$ Some degree of insulin resistance was also observed during the early period following AMI. ${ }^{18}$

In another study by Uluganyan $\mathrm{M}$, et al., the mortality was $2.4 \%$ in patients with low serum potassium levels with acute myocardial infarction. ${ }^{8}$

There are certain limitations in this study. Being observational, and despite using newer and sturdy methods with statistical analyses, a possibility of residual confounding still exists, i.e serum potassium level and untoward events may be linked reversely. Specifically, the high Odds Ratio for mortality at low potassium levels $(<3.0)$ are only based on limited events, are likely to be affected by outliers and rather than showing a causal relationship, may be attributed to severe illness. So large clinical trials showed be carried out targeting different $\mathrm{K}+$ levels in patients with AMI so as to define the optimal range. Ahead of large trials, based on the findings of our study, we would not recommend very aggressive treatment of low $\mathrm{K}+$ levels in the 3.5 to $3.9 \mathrm{mEq} / \mathrm{L}$ range as levels of $<4.5 \mathrm{mEq} / \mathrm{L}$ may not be very harmful.. Our study was conducted only in patients with AMI so these reference values may not be applicable in patients 
with other cardiac conditions e.g., congestive cardiac failure. Lately, a trial conducted on congestive cardiac failure patients documented an increased death rate in patients having serum $\mathrm{K}+$ levels less than $4.0 \mathrm{mEq} / \mathrm{L}$, but $\beta$-blockers known for causing high potassium levels and lowering mortality rates were not used in that study. ${ }^{19}$ We recommend studies similar to ours to be conducted in patients with congestive cardiac failure and a consensus development on serum $\mathrm{K}+$ levels with the aim to reduce mortality in these patients.

\section{Conclusion}

We concluded that admission serum potassium level was significantly associated with increased adverse outcome in patients with acute myocardial infarction. A low serum potassium level i.e., $<3.0 \mathrm{mEq} / \mathrm{L}$ was associated with higher mortality.

\section{Conflict of Interest: None}

\section{References}

1. Madias JE, Shah B, Chintalapally G, Chalavarya G, Madias NE. Admission serum potassium in patients with acute myocardial infarction: its correlates and value as a determinant of in-hospital outcome. Chest. 2000;118(4):904-913.

2. Braunwald E. Heart failure. JACC Heart Fail. 2013; 1:1-20. doi:10.1016/j.jchf.2012.10.002.

3. Krogager ML, Eggers-Kaas L, Aasbjerg K, Mortensen RN, Kober L, Gislason G,et al. Short-term mortality risk of serum potassium levels in acute heart failure following myocardial infarction. Eur Heart J Cardiovasc Pharmacother.2015;1(4):245-51.

4. Choi JS, Kim YA, Kim HY, Oak CY, Kang YU, Kim CS, et al. Relation of serum potassium level to longterm outcomes in patients with acute myocardial infarction. Am J Cardiol. 2014;113(8):1285-90.

5. Dixon DL, Abbate A. Potassium levels in acute myocardial infarction: definitely worth paying attention to. Eur Heart J Cardiovasc Pharmacother. 2015; 1(4): 252-3.

6. Shiyovich A, Gilutz H, Plakht Y. Serum potassium levels and long-term post discharge mortality in acute myocardial infarction. Int J Cardiol. 2014; 172(2): e368-370.

7. Goyal A, Spertus JA, Gosch K, Venkitachalam L, Jones PG, Van den Berghe G, et al. Serum potassium levels and mortality in acute myocardial infarction. JAMA. 2012;307(2):157-64.

8. Uluganyan M, Ekmekçi A, Murat A, Avşar Ş, Ulutaş $\mathrm{TK}$, Uyarel $\mathrm{H}$, et al. Admission serum potassium level is associated with in-hospital and long-term mortality in ST-elevation myocardial infarction. Anatol J Cardiol. 2016;16(1):10-5.
9. Macdonald JE, Struthers AD. What is the optimal serum potassium level in cardiovascular patients? $\mathrm{J}$ Am Coll Cardiol. 2004;43(2):155-61.

10. Commentary on Goyal A, Spertus JA, Gosch K, et al. Serum potassium levels and mortality in acute myocardial infarction. JAMA. 2012;307(2):157-164.

11. Friedensohn A, Faibel HE, Bairey O, Goldbourt U, Schlesinger Z. Malignant arrhythmias in relation to values of serum potassium in patients with acute myocardial infarction. Int J Cardiol 1991;32(3):331-8.

12. Cohn JN, Kowey PR, Whelton PK, Prisant LM. New guidelines for potassium replacement in clinical practice: a contemporary review by the National Council on Potassium in Clinical Practice. Arch Intern Med 2000; 160(16):2429-36.

13. Nordrehaug JE, Johannessen KA, von der Lippe G. Serum potassium concentration as a risk factor of ventricular arrhythmias early inacute myocardial infarction. Circulation 1985; 71(4): 645-9.

14. Park KL, Goldberg RJ, Anderson FA, Lopez-Sendon J, MontalescotG, Brieger D, et al. Beta-blocker Use in ST-segment Elevation Myocardial Infarction in the Reperfusion Era(GRACE).Am J Med 2014; 127(6): 503-11.

15. Norwegian Multicenter Study Group. Timolol-induced reduction in mortality and reinfarction in patients surviving acute myocardial infarction. N Engl J Med 1981;304(14):801-7.

16. Fitzovich DE, Hamaguchi M, Tull WB, Young DB. Chronic hypokalemia and the left ventricular responses to epinephrine and preload. J Am Coll Cardiol 1991; 18(4):1105-11.

17. Ekmekci A, Uluganyan M, Tufan F, Uyarel H, Karaca $\mathrm{G}, \mathrm{Kul} \mathrm{S}$, et al.Impact of admission blood glucose levels on prognosis of elderly patients with ST elevation myocardial infarction treated by primary percutaneous coronary intervention. J Geriatr Cardiol 2013;10(4):310-6.

18. Alper AB, Campbell RC, Anker SD,Bakris G, Wahle $\mathrm{C}$, Love TE et al. A propensity-matched study of low serum potassium and mortality in older adults with chronic heart failure. Int J Cardiol. 2009;137(1):1-8.

19. Digitalis Investigation Group. The effect of digoxin on mortality and morbidity in patients with heart failure. N Engl J Med. 1997;336(8):525-33.

\section{Authors Contribution}

RA, TN: Conceptionlization of Project

RA, BA, FS, MN : Data Collection

TN, BA, KN: Literature Research

KN, MN: Statistical Analysis

RA, TN, FS: Drafting, Revision

TA, BA: Writing of Manuscript 